\title{
LETTERS
}

\section{Tenosynovitis with acute onset: unexpected giant cell tumour of the tendon sheath}

\author{
E Kruithof, D Baeten, P Dierckxsens, E M Veys, F De Keyser
}

Ann Rheum Dis 2002;61:847

$\mathrm{T}$ he "case study in diagnostic imaging", reported by Peh et al illustrates nicely a giant cell tumour of the tendon sheath as a slowly progressing, mildly tender mass of the wrist. ${ }^{1}$ Here we report another case of giant cell tumour of the tendon sheath, which had an unusual disease onset.

A 33 year old man presented with acute swelling and severe pain of the palmar side of the right hand. He had symptoms of carpal tunnel syndrome, and upon clinical examination swelling of the flexor tendon sheaths of the wrist as well as the fourth and fifth fingers was seen. There was no history of trauma or exposure to tuberculosis.

His erythrocyte sedimentation rate and $\mathrm{C}$ reactive protein were within the normal range; rheumatoid factor was absent. Mantoux testing and a chest $x$ ray examination were negative. A radiograph of the right hand was normal. Because of deteriorating pain and swelling, a surgical exploration with tenosynovectomy was performed. Macroscopically this showed an exuberant brownish synovial proliferation with numerous villonodular projections, which was not encapsulated. There was no evidence for recent haemorrhage. Histological examination showed proliferation of the synovial lining, subintimal infiltration with mononuclear polyhedral cellsoften with a histiocytic aspect, scattered multinucleated giant cells (fig lA), and haemosiderin laden and lipid laden macrophages (fig 1B). Although the infiltrate was markedly dense, regional variations in cellularity were seen. Compact areas alternated with more non-cohesive zones with cleft-like spaces appearing as artificial tears. This histological pattern is characteristic for a diffuse giant cell tumour of the tendon sheath, which is histologically very similar to pigmented villonodular synovitis. ${ }^{2}$

Differential diagnosis of tenosynovitis of the hand with occurrence of multinucleated giant cells is a feature of rheumatic diseases such as rheumatoid arthritis, tubercular and non-tubercular mycobacterial infections, and foreign body granulomas. ${ }^{3-5}$ In this patient neither his history or additional examinations suggested these diseases, although acute onset and severe pain are not commonly reported in giant cell tumour of the tendon sheath.

\section{Authors' affiliations \\ E Kruithof, D Baeten, E M Veys, F De Keyser, Department of Rheumatology, Ghent University Hospital, Belgium \\ P Dierckxsens, Department of Orthopaedics, KLINA Hospital, Belgium}

Correspondence to: Dr E Kruithof, Department of Rheumatology, OK 12IB, Ghent University Hospital, De Pintelaan 185, 9000 Gent, Belgium; elli.kruithof@rug.ac.be

Accepted 11 April 2002

\section{REFERENCES}

1 Peh WCG, Shek TWH, Ip WY. Growing wrist mass. Ann Rheum Dis 2001;60:550-3

2 de Saint Aubain Somerhausen N, Fletcher C. Diffuse-type giant cell tumor. Clinicopathologic and immunohistochemical analysis of 50 cases with extraarticular disease. Am J Surg Pathol 2000;24:479-92.

3 Goldring SR, Gravallese EM. Pathogenesis of bone erosions in rheumatoid arthritis. Curr Opin Rheumatol 2000; 12:195-9.

4 Toussirot E, Chevrolet A, Wendling D. Tenosynovitis due to Mycobacterium avium intracellullare and Mycobacterium chelonei: report of two cases with review of the literature. Clin Rheumatol 1998; 17:152-6.

5 Reginato AJ, Ferreiro JL, O'Connor CR, Barbasan C, Arasa J, Bednar J, et al. Clinical and pathologic studies of 26 patients with penetrating foreign body injury to the joints, bursae, and tendon sheaths. Arthritis Rheum 1990;33:1753-62.
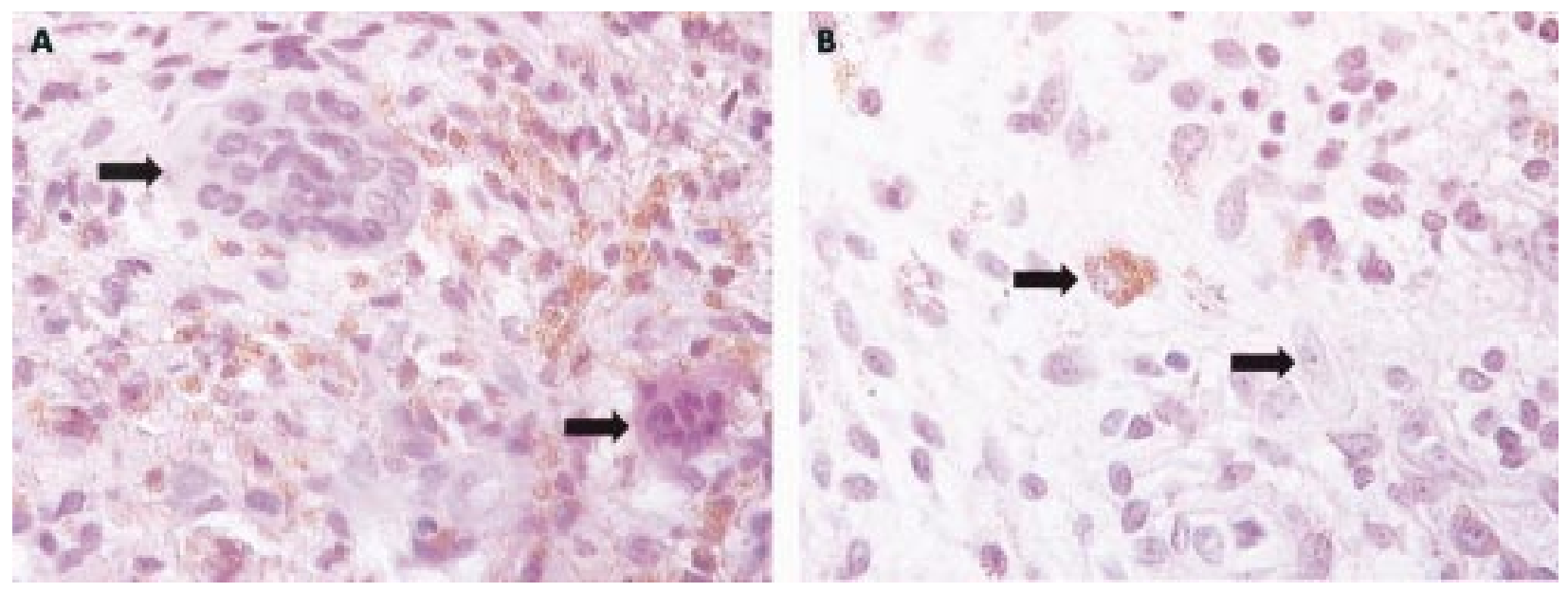

Figure 1 Tenosynovial biopsy on light microscopy. (A) Multinucleated giant cells in a background of mononuclear cells with abundant extracellular haemosiderin deposition (paraffin embedded section, haematoxylin and eosin stain, magnification $\times 640$ ). (B) Haemosiderin laden macrophages and lipid laden macrophages (foamy cells) (paraffin embedded section, haematoxylin and eosin stain, magnification $\times 640$ ). 


\title{
Fulminant necrotising fasciitis developing during long term corticosteroid treatment of systemic lupus erythematosus
}

\author{
N Hashimoto, H Sugiyama, K Asagoe, K Hara, O Yamasaki, Y Yamasaki, H Makino
}

S kin manifestations are some of the most common clinical symptoms and signs seen in patients with systemic lupus erythematosus (SLE). However, necrotising subcutaneous infection, in particular necrotising fasciitis, is rarely encountered. It is a rapidly progressive and destructive infection of the subcutaneous tissue, associated with mortality and long term morbidity of the affected patients. ${ }^{1}$ We describe a patient with SLE and liver cirrhosis complicated by severe necrotising fasciitis who had been receiving corticosteroid treatment for 20 years. Necrotic skin tissue cultures grew both Staphylococcus aureus and Serratia marcescens. Despite aggressive treatment, including administration of antibiotics, emergency debridement, and total plasma exchange for severe liver damage, she died of disseminated intravascular coagulation and multiple organ failure owing to serious bacterial infection after two months in hospital. This case suggests that severe necrotising fasciitis may occur in SLE without lupus flare up during long term treatment with low dose corticosteroids.

\section{CASE REPORT}

A 58 year old Japanese woman, who had been receiving oral prednisolone treatment for SLE for 20 years, was admitted to our hospital because of a swollen and erythematous left leg. She had taken $5 \mathrm{mg}$ prednisolone daily for more than 10 years and no other immunosuppressive agents. She had had liver cirrhosis due to hepatitis $C$ virus infection five years earlier. In December 1999 she had small wound in her left ankle. There was widespread violaceous discolouration of the skin and scattered bullae over the left knee and thigh with oedema extending from the ankle to mid-calf (fig lA). On admission, she was in septic shock and had multiple organ failure, including hepatic and renal dysfunction. Her vital signs on arrival were blood pressure $82 / 62 \mathrm{mmHg}$, body temperature $38.0^{\circ} \mathrm{C}$, pulse rate 80 beats $/ \mathrm{min}$, and respiratory rate $18 / \mathrm{min}$. She had jaundice without ascites. She was alert and answered questions properly. Laboratory investigations showed a white blood cell count of $21.6 \times 10^{9} / 1$ with $54 \%$ segmented and $29 \%$ bands, a haemoglobin level of $131 \mathrm{~g} / \mathrm{l}$, a platelet count of $133 \times 10^{9} / 1$, C reactive protein (CRP) $130 \mathrm{mg} / \mathrm{l}$, blood urea nitrogen $17.9 \mathrm{mmol} / \mathrm{l}$ of urea, creatinine $216 \mu \mathrm{mol} / \mathrm{l}$, aspartate aminotransferase $135 \mathrm{IU} / \mathrm{l}$, alanine aminotransferase $90 \mathrm{IU} / \mathrm{l}$, and total bilirubin $136 \mu \mathrm{mol} / \mathrm{l}$. Blood glucose was $5.8 \mathrm{mmol} / \mathrm{l}$, and glycohaemoglobin was 0.052 . Immunoserological analysis showed C3 $0.4 \mathrm{~g} / \mathrm{l}, \mathrm{C} 40.3 \mathrm{~g} / \mathrm{l}, \mathrm{CH}_{50} 18.4 \mathrm{U} / \mathrm{ml}$, and anti-double stranded DNA antibody $5 \mathrm{U} / \mathrm{ml}$. Blood culture was negative for bacteria or fungi. Antibodies to hepatitis $\mathrm{C}$ virus and its RNA were both positive. There was no cryoglobulinaemia.

Emergency debridement of the anterior, posterior, and lateral compartments of the left leg was performed. Methicillin sensitive Staphylococcus aureus and Serratia marcescens were recovered from necrotic tissue culture. Fosfomycin $4 \mathrm{~g} /$ day and sultamicillin tosilate $1.125 \mathrm{mg} /$ day were substituted for the initial broad spectrum antibiotics. A skin biopsy specimen including subcutaneous tissue showed extensive infiltration of inflammatory cells along the superficial fascia, a characteristic of necrotising fasciitis (fig 1B). Over the ensuing days her vital signs and renal function improved once. The CRP levels decreased to 30-50 mg/l, but her liver dysfunction worsened
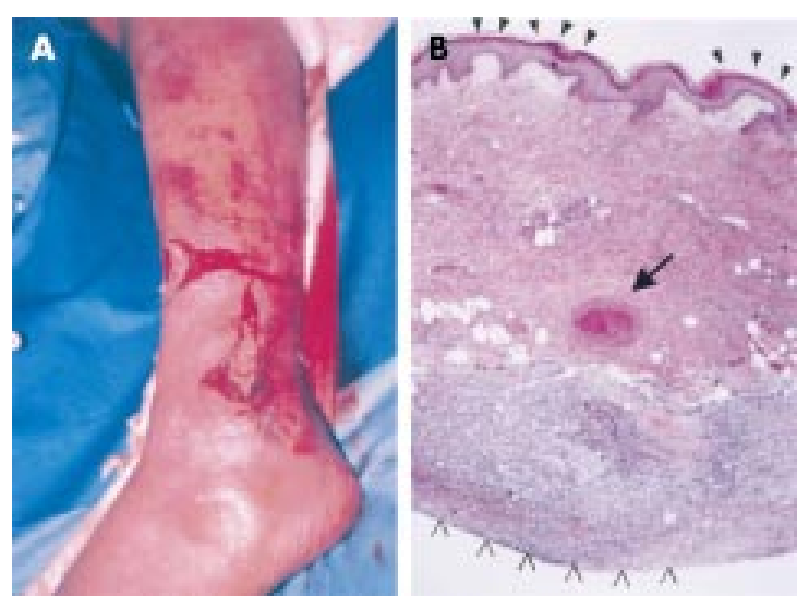

Figure 1 (A) Preoperative appearance of the swollen and erythematous left leg with purpura, skin ulcer, and bullae formation. (B) Light micrograph of skin biopsy specimens including superficial fascia. The arrow indicates thrombosis of subdermal blood vessels. Arrowheads denote epidermal detachment. Blisters show massive inflammatory cell infiltration in subcutaneous tissue and superficial fascia. (Haematoxylin and eosin, original magnification $\times 200$.)

and total plasma exchange was started on the 16th hospital day. She died of disseminated intravascular coagulation and multiple organ failure including hepatic failure eight weeks after the admission to hospital. There was no lupus flare up during the treatment of necrotising fasciitis.

\section{DISCUSSION}

Infection is a major cause of death in patients with SLE. ${ }^{2}$ Active SLE itself contains many forms of immunological dysfunction, which may account for the increased susceptibility to infection. The abnormalities include acquired and inherited complement deficiencies, immunoglobulin deficiency, defects in chemotaxis, phagocytic activity, and delayed hypersensitivity. Even in clinical remission, an increased tendency to develop infections has been reported among patients with SLE. ${ }^{3}$ The decreased complement level in our patient might have been caused by consumption due to severe infection because there were no clinical symptoms of lupus flare up before and after admission to hospital.

Treatment with corticosteroids and other immunosuppressive agents may further have affected the increased susceptibility to infection. Corticosteroids decrease inflammatory response, effector cell response in cell mediated immunity, and immunoglobulin synthesis. ${ }^{4}$ Necrotising fasciitis is uncommon but might occur in SLE during immunosuppression due to high dose corticosteroid treatment. ${ }^{56}$ In this condition Serratia marcescens might be a potential pathogen causing necrotising fasciitis in susceptible hosts. ${ }^{6}$ In our patient, prolonged steroid administration might have increased the risk of infection and caused the fragility of skin tissue, which in turn allowed easy access of bacteria into the circulation. Liver cirrhosis may be associated with necrotising fasciitis caused by an infection of enteric bacterium such as Escherichia 
coli or Klebsiella species through ascitic fluid. ${ }^{7}$ This possibility is unlikely in our patient because she had no ascites while in hospital. Liver failure instead affected the decreased complement production in our patient.

The case presented here suggests that long term administration of corticosteroids even in a low dose may be a risk factor for fatal infection such as necrotising fasciitis in patients with SLE.

Authors' affiliations

N Hashimoto, H Sugiyama, Y Yamasaki, H Makino, Department of Medicine and Clinical Science (Department of Medicine III), Okayama University Graduate School of Medicine and Dentistry, 2-5-1 Shikata-cho, Okayama 700-8558, Japan

K Asagoe, K Hara, O Yamasaki, Department of Dermatology,

Okayama University Graduate School of Medicine and Dentistry

Correspondence to: Dr N Hashimoto; hashid@mail.goo.ne.jp

Accepted 27 March 2002

\section{REFERENCES}

1 Ahrenolz DH. Necrotizing soft tissue infections. Surg Clin North Am 1988:68:199-214.

2 Ginzler EM. Infections in systemic lupus erythematosus. In: Wallace DJ, Hahn BH, eds. Dubois' lupus erythematosus. Philadelphia: Williams and Wilkins, 1997:903-13.

3 Staples PJ, Gerding DN, Decker JL, Gordon RS Jr. Incidence of infection in systemic lupus erythematosus. Arthritis Rheum 1974;17: $1-10$.

4 Boumpas DT, Paliogianni F, Anastassiou ED, Balow JE. Glucocorticosteroid action on the immune system: molecular and cellular aspects. Clin Exp Rheumatol 1991;9:413-23.

5 Mendez EA, Espinoza LM, Harris M, Angulo J, Sanders CV, Espinoza LR. Systemic lupus erythematosus complicated by necrotizing fasciitis. Lupus 1999;9:157-9.

6 Huang JW, Fang CT, Hung KY, Hsueh PR, Chang SC, Tsai TJ. Necrotizing fasciitis caused by Serratia marcescens in two patients receiving corticosteroid therapy. J Formos Med Assoc 1999;98:851-4

7 Ho PL, Tang WM, Yuen KY. Klebsiella pneumoniae necrotizing fasciitis associated with diabetes and liver cirrhosis. Clin Infect Dis 2000; 30:989-90.

\section{Repeated arthralgia associated with granulocyte colony stimulating factor administration}

\section{A Tsukadaira, Y Okubo, S Takashi, H Kobayashi, K Kubo}

\section{CASE REPORT}

We report the case of a 69 year old man with non-small lung cancer, who developed arthralgia and myalgia twice during chemotherapy using $210 \mathrm{mg} /$ day of paclitaxel and 110 $\mathrm{mg} /$ day of nedaplatine for every four week cycle. After starting chemotherapy, arthralgia and myalgia accompanied by rising fever suddenly occurred on the fifth consecutive day of subcutaneous administration of $100 \mu \mathrm{g}$ /day of granulocyte colony stimulating factor (G-CSF; lenograstim). To determine the cause of the polyarthralgia we carried out arthroscopy in the most symptomatic joint. The left elbow and left hand joints were chosen for the biopsy. Microscopic findings of formalin fixed synovial tissue showed severe inflammatory infiltration accompanied by foreign body-type giant cell reaction, but no crystals or rheumatoid nodules (fig 1).

During the second cycle of chemotherapy we obtained the patient's informed consent to keep his serum at $-80^{\circ} \mathrm{C}$ for assessment of drug toxicity. He was treated with the same doses of paclitaxel and nedaplatine as for the first cycle, and G-CSF was also given from day 10 after the start of chemotherapy. On day 5 after G-CSF administration, fever and

Table 1 Laboratory findings

\begin{tabular}{llll}
\hline & Day 0 & Day 8 & Day 16 \\
\hline WBC $\left(\times 10^{9} /\right.$ I) & 5.3 & 1.2 & 10.4 \\
CRP $(\mathrm{mg} / \mathrm{ll})$ & 2.0 & 12.6 & 80 \\
Histamine $(\mathrm{pg} / \mathrm{ml})$ & 550 & 960 & 350 \\
G-CSF $(\mathrm{pg} / \mathrm{ml})$ & 16.8 & 31.5 & 36.6 \\
IL8 $(\mathrm{pg} / \mathrm{ml})$ & $<10$ & $<10$ & 25.4
\end{tabular}

Day 0 , before infusions of paclitaxel and nedaplatine; day 8 , before subcutaneous G-CSF administration; day 16, during the attack. WBC, white blood cells; CRP, C reactive protein; G-CSF, granulocyte colony stimulating factor; IL, interleukin.

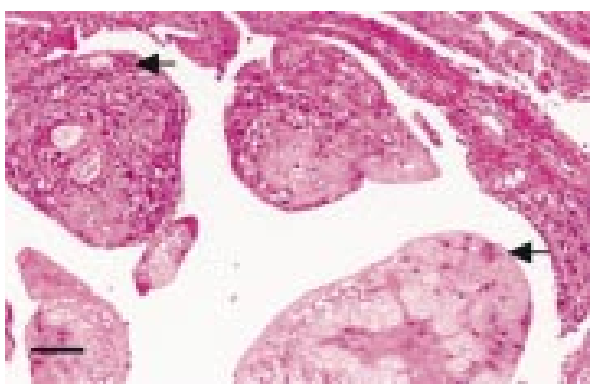

Figure 1 Microscopic findings of synovial tissue in the left elbow joint. The synovial membrane is hypertrophied and fine microvilli can be seen. Amorphous eosinophilic material deposition accompanied by foreign body-type giant cell reaction (arrows) was seen. Haematoxylin and eosin staining, $\times 100$. Bar represents $100 \mu \mathrm{m}$.

grade 2 myalgia in the legs suddenly developed. During the attack, granulocytosis (neutrophil cell count $10.4 \times 10^{9} / 1$ ) and a raised level of $\mathrm{C}$ reactive protein $(80 \mathrm{mg} / \mathrm{l})$ were seen. Before the two cycles of systemic chemotherapy, gallium scintigraphy and magnetic resonance imaging showed thoracic spinal metastasis. However, thyroid function, parathyroid function, renal function, uric acid serum levels, and electrolytes in the peripheral blood were within normal limits. Rheumatoid factor or autoimmune antibodies in the serum were negative. Neutrophil cell count, $\mathrm{C}$ reactive protein and histamine levels, and G-CSF and interleukin 8 (IL8) concentrations in the peripheral blood were examined on days 0,8 , and 16 (during the attack) (table 1).

\section{DISCUSSION}

Arthralgia and myalgia are well known side effects of long term infusion of paclitaxel, usually lasting for $2-6$ days ${ }^{1}$ On the 
other hand, G-CSF induced bone and generalised muscle pain are considered to be rare side effects during the neutrophil recovery phase. ${ }^{12}$ Histamine has been suggested to be one of the chemical mediators which cause oedema in bone; the resultant increase in pressure leads to pain. ${ }^{3}$ Gudi et al reported that histamine induced arthritis during chemotherapy combined with G-CSF administration. ${ }^{4}$ It has also been reported that paclitaxel-induced arthralgia or myalgia is augmented by G-CSF. ${ }^{5}$ Recently, pseudogout during systemic high dose chemotherapy with G-CSF administration ${ }^{67}$ or reactivation of rheumatoid arthritis in Felty's syndrome treated with G-CSF have been reported. ${ }^{8}$

For this report we assessed the relationship between clinical course and laboratory findings. Polyarthralgia and myalgia with rising fever developed on the fifth consecutive day of subcutaneous administration of G-CSF. Peak concentrations of histamine in the serum showed on day 8, but the serum IL8 concentration was higher during the attack. G-CSF mediated acute synovitis accompanied by foreign body-type giant cell reaction was suggested to be a cause of the rising fever and raised levels of serum IL8.

On the basis of these findings, G-CSF mediated nonrheumatic synovitis with foreign body-type giant cell reaction is suspected to possess a new responsiveness to G-CSF during chemotherapy. Close observation of a greater numbers of cases will be necessary to determine which insidious joint diseases may be caused by G-CSF.

\section{ACKNOWLEDGEMENT}

This work was supported in part by grant in aid for science research No 12670421 from the Ministry of Education in Japan.

\section{Authors' affiliations}

A Tsukadaira, S Takashi, K Kubo, First Department of Internal

Medicine, Shinshu University School of Medicine, Japan

Y Okubo, Department of Internal Medicine, National Higashinagano Hospital, Japan

H Kobayashi, Department of Orthopaedics, Shinshu University School of Medicine, Japan

Correspondence to: Dr Y Okubo, Department of Internal Medicine, Higashinagano National Hospital, Uwano 2-477, Nagano, 381-8567, Japan; okuboyo@enagano.hosp.go.jp

Accepted 27 February 2002

\section{REFERENCES}

1 Schiller JH, Storer B, Tutsch K, Arzoomanian R, Alberti D, Feierabend C, et al. Phase I trial of 3-hour infusion of paclitaxel with or without granulocyte colony-stimulating factor in patients with advanced cancer. J Clin Oncol 1994;12:241-8.

2 Miller LL. Current status of G-CSF in support of chemotherapy and radiotherapy. Oncology 1993;7:67-88.

3 Bennett A. The role of biochemical mediators in peripheral nociception and bone pain. Cancer Surv 1988;7:55-67.

4 Gudi R, Krishnamurthy M, Pachter BR. Astemizole in the treatment of granulocyte colony-stimulating factor-induced bone pain. Ann Intern Med $1995 ; 123: 236-7$.

5 Schiller JH, Storer B, Tutsch K, Arzoomanian R, Alberti D, Feierabend C et al. A phase I trial of 3-hour infusions of paclitaxel (Taxol) with or without granulocyte colony-stimulating factor. Semin Oncol 1994;21 (suppl 8):9-14.

6 Sandor V, Hassan R, Kohn E. Exacerbation of pseudogout by granulocyte colony-stimulating factor. Ann Intern Med 1996; 125:781.

7 Teramoto S, Yamamoto H, Ouchi Y. Increased synovial interleukin-8 and interleukin-6 levels in pseudogout associated with granulocyte colony-stimulating factor. Ann Intern Med 1998;129:424-5.

8 Vidarsson B, Geirsson AV, Onundarson PT. Reactivation of rheumatoid arthritis and development of leukocytoclastic vasculitis in a patient receiving granulocyte colony-stimulating factor for Felty's syndrome. Am J Med 1995;98:589-91

\section{Severe skin reaction after leflunomide and etanercept in a patient with rheumatoid arthritis}

\section{F Soliotis, M Glover, A S M Jawad}

Ann Rheum Dis 2002;61:850-851

\section{CASE HISTORY}

A 32 year old Pakistani woman developed a symmetrical polyarthritis, with a high erythrocyte sedimentation rate, in 1991. Within a few months, erosions developed and her rheumatoid factor became positive. The antinuclear antibodies were negative. Between 1991 and 1999 she was treated with sulfasalazine, sodium aurothiomalate, azathioprine, methotrexate, D-penicillamine, and hydroxychloroquine sequentially, but each drug had to be stopped either because of intolerance or leucopenia.

Her disease remained active and deformities developed. Her condition was maintained with $7.5 \mathrm{mg}$ oral prednisolone and non-steroidal anti-inflammatory drugs. In April 2000 leflunomide was added. Three daily doses of $100 \mathrm{mg}$ leflunomide were followed by $20 \mathrm{mg}$ a day maintenance dose. Ten days later, she developed a vesicular rash over the trunk and the proximal parts of the arms and legs (fig l). Leflunomide was discontinued and cholestyramine was introduced for wash out. A skin biopsy showed focal epidermal necrosis with partial lichenoid changes. Direct immunofluorescence was negative. The antinuclear and anti-dsDNA antibodies remained negative, but the anti-Ro antibodies were positive. No other features suggested a diagnosis of lupus. The dose of prednisolone was raised to $20 \mathrm{mg}$ a day and topical corticosteroids were used. The skin lesions healed within a month with residual pigmentation and the prednisolone dose was reduced to $7.5 \mathrm{mg}$ a day. Six months later there was a minor flare up of the rash. A skin biopsy showed resolving lichenoid changes.

Her arthritis remained active, and in February 2001 etanercept was introduced in a dose of $25 \mathrm{mg}$ subcutaneously twice a week. Treatment continued with $7.5 \mathrm{mg}$ prednisolone. A vesicular erythematous rash started after the second injection of etanercept, which worsened and spread to affect the trunk and the arms and legs after the fourth injection (fig 2). The rash was much more aggressive than the previous one. Etanercept was discontinued; the prednisolone dose was raised to $30 \mathrm{mg}$ a day. A skin biopsy again showed areas of central necrosis surrounded by a rim of perivascular inflammation and there was also an inflammatory infiltrate at the dermoepidermal junction with necrosis of the basal keratinocytes. Again the anti-Ro antibodies became positive and in a higher titre. The lesions took several months to settle leaving pigmented scars.

\section{DISCUSSION}

Leflunomide, an inhibitor of pyrimidine synthesis, has recently been introduced in the treatment of patients with 


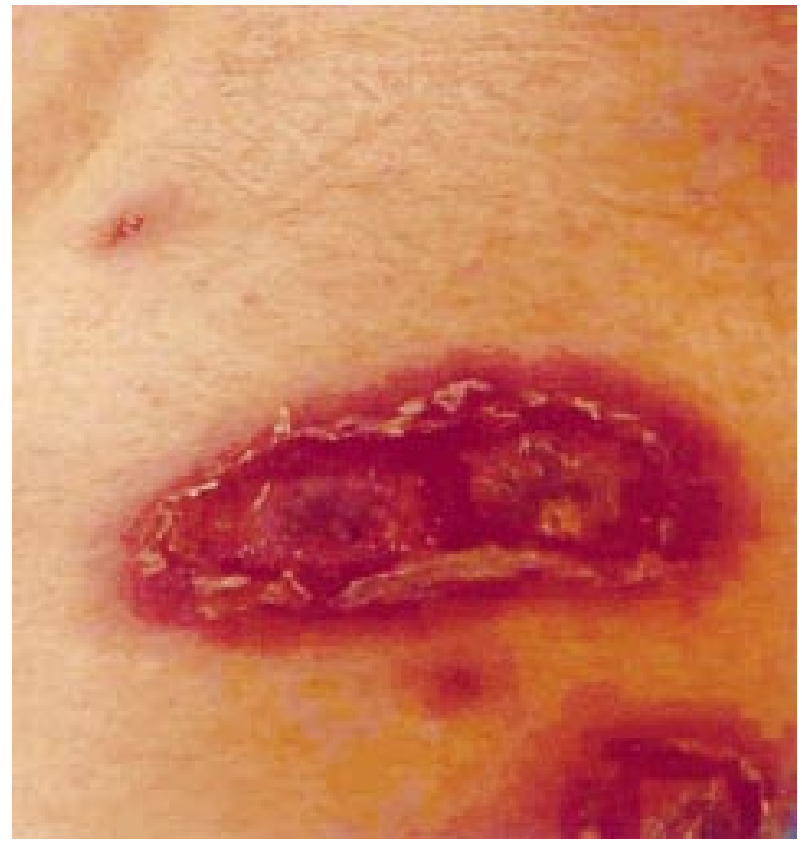

Figure 1 The leflunomide induced rash.

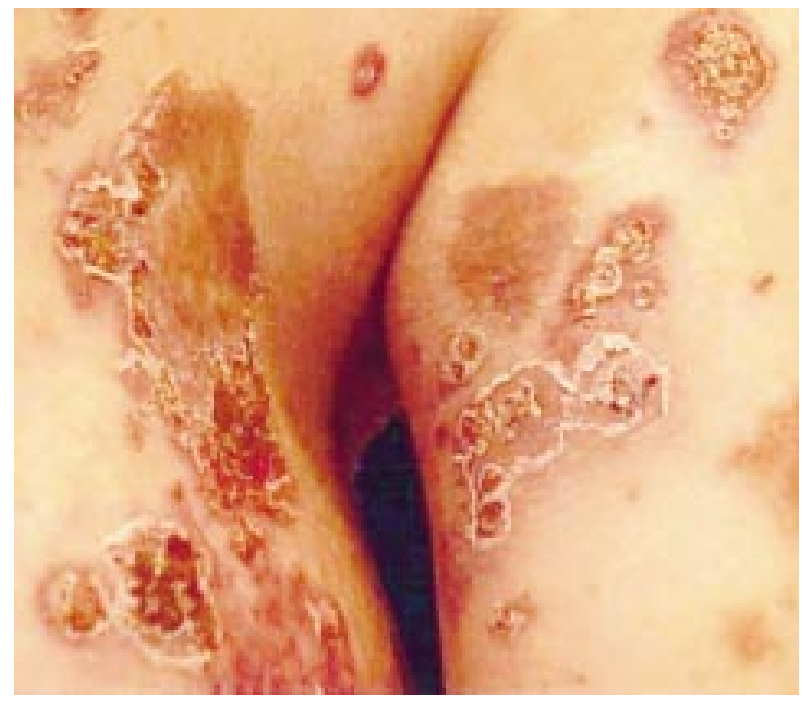

Figure 2 The etanercept induced rash.

rheumatoid arthritis (RA). ${ }^{1}$ Skin side effects include dry skin, alopecia, eczema, rash, pruritus, and, rarely, Steven-Johnson syndrome and toxic epidermal necrolysis. ${ }^{2}$

Etanercept is a human tumour necrosis factor receptor p75 Fc fusion protein that is used for the treatment of active RA if there is inadequate response to disease modifying antirheumatic drugs (DMARDs). A variety of skin rashes have been reported in controlled trials of etanercept in the treatment of RA. Most have been mild and only one reported case had a grade 3 rash (generalised symptomatic maculopapular or vesicular) (Wyeth Laboratories, unpublished data). The rash usually appears two to three weeks after the start of treatment.
Recently, three cases of acute discoid lupus and two cases of subacute cutaneous lupus erythematosus (SCLE) have been reported during treatment of patients with RA with etanercept. ${ }^{3}$ One of the two patients reported with SCLE developed anti-Ro antibodies. About $15 \%$ of patients treated with etanercept develop anti-dsDNA antibodies and 11\% develop antinuclear antibodies. ${ }^{5-7}$

Although our patient had positive anti-Ro antibodies, the blistering rash clinically and histologically was not in keeping with SCLE or other forms of lupus.

The initial leflunomide-induced rash (toxic epidermal necrosis) seen in our patient has been described previously. ${ }^{2}$ The rash that developed after etanercept was a more severe form of a similar drug induced reaction. Clinically and histologically the etanercept-induced rash was in keeping with erythema multiforme It took several months of treatment with moderate doses of prednisolone for the rash to settle. Erythema multiforme has been associated with drugs such as sulphonamides, antimalarial drugs, penicillin, and salicylates, infections, lymphomas, and systemic lupus erythematosus. Our patient did not have any features to suggest any concurrent infections, lymphoma, or lupus.

Our patient developed toxic epidermal necrosis after leflunomide and erythema multiforme after etanercept. Both skin reactions, which are often drug related, share a similar pathogenesis, which is also suggested by the appearance of anti-Ro antibodies. Our case highlights that serious skin reaction to more than one DMARD including etanercept can occur in susceptible patients. What factor or immune phenotype determines this outcome is not clear. However, it poses a serious problem in the management of certain patients with RA.

\section{Authors' affiliations}

F Soliotis, A S M Jawad, Department of Rheumatology, The Royal London Hospital, Bancroft Road, London E I 4DG, UK

M Glover, Department of Dermatology, St Andrews Hospital, Devons Road, London E3 3NT, UK

Correspondence to: Dr A S M Jawad, Department of Rheumatology, The Royal London Hospital, 275 Bancroft Road, Mile End, London El 4DG, UK; alismjawad1@hotmail.com

Accepted 4 April 2002

\section{REFERENCES}

1 Laan RFJM, van Riel PLCM, van de Putte LBA. Leflunomide and methotrexate. Curr Opin Rheumatol 2001;13:159-63.

2 Smolen JS, Emery P. Efficacy and safety of leflunomide in active rheumatoid arthritis. Rheumatology (oxford) 2000;39(suppl 1):48-56.

3 Brion PH, Mittal-Henkle A, Kalunian KC. Autoimmune skin rashes associated with etanercept for rheumatoid arthritis. Ann Intern Med 1999; 131:634.

4 Bleumink GS, ter Borg EJ, Ramselaar CG, Stricker BHCh. Etanercept-induced subacute cutaneous lupus erythematosus. Rheumatology (Oxford) 2001;40:1317-19.

5 Moreland LW, Schiff MH, Baumgartner SW, Tindall EA, Fleischmann RM, Bulpitt KJ, et al. Etanercept therapy in rheumatoid arthritis: a randomized, controlled trial. Ann Intern Med 1999;130:478-86.

6 Weinblatt ME, Kremer JM, Bankhurst AD, Bulpitt KJ, Fleischmann RM, Fox Rl, et al. A trial of etanercept, a recombinant tumor necrosis factor receptor:Fc fusion protein, in patients with rheumatoid arthritis receiving methotrexate. N Engl J Med 1999:340:253-9.

7 Russell E, Zeihen M, Wergin S, Litton T. Patients receiving etanercept may develop antibodies that interfere with monoclonal antibody laboratory assays. Arthritis Rheum 2000;43:944. 


\title{
Clinical, radiographic, and thermographic assessment of osteoarthritis in the knee joints
}

\author{
H Warashina, Y Hasegawa, H Tsuchiya, S Kitamura, K-I Yamauchi, Y Torii, \\ M Kawasaki, S Sakano
}

Ann Rheum Dis 2002;61:852-854

t has been reported that thermography enables the evaluation of non-steroidal anti-inflammatory drugs for the treatment of rheumatic synovitis. ${ }^{12}$ However, few reports mentioned the relation between skin temperature and symptoms, physical signs, and radiographic features in patients with osteoarthritis (OA). In this study we evaluated the correlation between radiographic and clinical findings and skin temperature measured by thermography for the assessment of $\mathrm{OA}$ in the knee joints in the Comprehensive Health Examination Programme at Y-town, Japan in 1999. ${ }^{3}$

\section{PATIENTS AND METHODS}

The assessments were performed on 974 knees of 169 men and 318 women who had a mean (SD) age of 57.6 (4.3). The following physical examinations of the knees were carried out: local tenderness, joint swelling, local heat, McMurray test, Lachmann test, instability of collateral ligaments, patellofemoral joint (PFJ) grinding test, range of joint motion, and thigh girth. Walking and stair climbing ability were graded using the Hospital for Special Surgery (HSS) knee rating scores and Lysholm knee scoring scale. ${ }^{4}$ Present or past pain continuing for more than one month was recorded.

The distance between the medial and lateral tibiofemoral joints (MTFJ and LTFJ) was measured on the anteroposterior radiographs. Radiographic scoring of osteophytes ( 0 , none; 1 , doubtful; 2, minimal; 3, moderate) at four sites (medial and lateral condyle of both tibia and femur) was recorded. ${ }^{5}$
The thermographic index (TI) and heat distribution index (HDI) were obtained by thermographic apparatus (TH5108ME, NEC Medical Systems, Japan). The TI has been defined as the average surface temperature of local skin area ${ }^{6}$ and HDI as \pm 1 SD from the mean surface temperature. ${ }^{7}$ The whole anterior knee of $10 \mathrm{~cm}^{2}$ was assessed for HDI. Three different areas of $3 \times 3 \mathrm{~cm}$ were studied for TI: $\mathrm{T}_{\mathrm{m}}$, TI of MTFJ; $\mathrm{T}_{1}$, TI of LTFJ; and $\mathrm{T}_{\mathrm{p}}$, TI of $10 \mathrm{~cm}$ above the patella. $\mathrm{T}_{\mathrm{p}}$ was considered as the control value. To minimise the effect of the variation of individual skin temperature, normalised $\mathrm{T}_{\mathrm{m}}$ and $\mathrm{T}_{1}$ $\left(\Delta \mathrm{T}_{\mathrm{m}}\right.$ and $\left.\Delta \mathrm{T}_{1}\right)$ were calculated by subtracting $\mathrm{T}_{\mathrm{p}}$ from $\mathrm{T}_{\mathrm{m}}$ and $\mathrm{T}_{\mathrm{l}}$ $\left(\Delta \mathrm{T}_{\mathrm{m}}=\mathrm{T}_{\mathrm{m}}-\mathrm{T}_{\mathrm{p}}, \Delta \mathrm{T}_{1}=\mathrm{T}_{1}-\mathrm{T}_{\mathrm{p}}\right)$. High $\Delta \mathrm{T}_{\mathrm{m}}$ means high skin temperature on MTFJ and high $\Delta \mathrm{T}_{1}$ means high skin temperature on LTFJ. Residents with severe knee deformity, rheumatoid arthritis, vascular disease, positive sign of PFJ grinding test were excluded, because we focused on the OA change of the MTFJ and LTFJ in this study.

Statistical analyses were carried out by unpaired Student's $t$ test, Pearson's correlation coefficient test, and Kruskal-Wallis test. A p value of $<0.05$ was considered significant.

\section{RESULTS}

The thermographic and radiographic findings showed that narrowing of the MTFJ space was significantly associated with a rise in skin surface temperature $(\mathrm{p}<0.01)$ (table 1$). \Delta \mathrm{T}_{\mathrm{m}}$ correlated significantly with the size of osteophytes at all sites measured, and $\Delta \mathrm{T}_{1}$ correlated at two of four sites (fig 1). These

Table 1 Correlation between radiographic, clinical assessments, and normalised $\mathrm{TI}\left(\Delta \mathrm{T}_{\mathrm{m}}, \Delta \mathrm{T}_{\mathrm{l}}\right)$

\begin{tabular}{|c|c|c|c|c|c|c|}
\hline & \multicolumn{3}{|c|}{ Normalised $\mathrm{T}_{\mathrm{m}}$} & \multicolumn{3}{|l|}{ Normalised $T_{1}$} \\
\hline & $\begin{array}{l}\text { Mean value } \\
\text { (SD) }\end{array}$ & $\begin{array}{l}\text { Correlation } \\
\text { coefficient }\end{array}$ & p Value & $\begin{array}{l}\text { Mean value } \\
\text { (SD) }\end{array}$ & $\begin{array}{l}\text { Correlation } \\
\text { coefficient }\end{array}$ & p Value \\
\hline Distance of MTFJ & & 0.548 & $<0.001$ * * & & 0.232 & NS \\
\hline Distance of LTFJ & & 0.106 & NS & & 0.247 & NS \\
\hline Present pain & & & $<0.001$ ** & & & $<0.001$ ** \\
\hline Past pain & & & $<0.001$ ** & & & $<0.001$ ** \\
\hline Tenderness & & & $<0.001$ ** & & & $0.001 * *$ \\
\hline Joint swelling & & & $0.006 * *$ & & & $0.001 * *$ \\
\hline Local heat & & & $<0.001$ ** & & & $0.019 *$ \\
\hline McMurray test & & & $0.001 * *$ & & & $0.001 * *$ \\
\hline Lachmann test & & & NS & & & NS \\
\hline Instability of collateral ligaments & & & 0.001 ** & & & $0.002 * *$ \\
\hline \multicolumn{7}{|l|}{ Walking ability } \\
\hline Walking and standing unlimited & $0.62(0.82)$ & & $<0.001$ ** & $1.98(6.31)$ & & $0.017^{*}$ \\
\hline 5-10 Blocks, standing $>50 \mathrm{~min}$ & $0.31(0.71)$ & & & $1.02(0.82)$ & & \\
\hline $1-5$ Blocks, standing $15-50 \mathrm{~min}$ & $0.19(0.74)$ & & & $0.85(0.81)$ & & \\
\hline Walking $<1$ block & $0.48(1.08)$ & & & $0.71(0.84)$ & & \\
\hline \multicolumn{7}{|l|}{ Stair climbing ability } \\
\hline No problem & $0.66(0.80)$ & & $<0.001$ ** & 1.52 (5.79) & & $0.005^{* *}$ \\
\hline Slightly impaired & $0.45(0.87)$ & & & $1.38(0.8)$ & & \\
\hline One step at a time & $0.16(0.72)$ & & & $0.93(0.86)$ & & \\
\hline Impossible & $1.3(0.42)$ & & & 0.65 (092) & & \\
\hline Knee operation experience & & & NS & & & NS \\
\hline \multicolumn{7}{|l|}{ Range of knee motion } \\
\hline Flexion & & -0.654 & $<0.001$ ** & & -0.666 & $0.004 * *$ \\
\hline Extension & & -0.435 & $<0.001 * *$ & & -0.486 & $0.008 * *$ \\
\hline Thigh girth & & -0.479 & $0.015^{*}$ & & -0.472 & $0.027^{*}$ \\
\hline
\end{tabular}



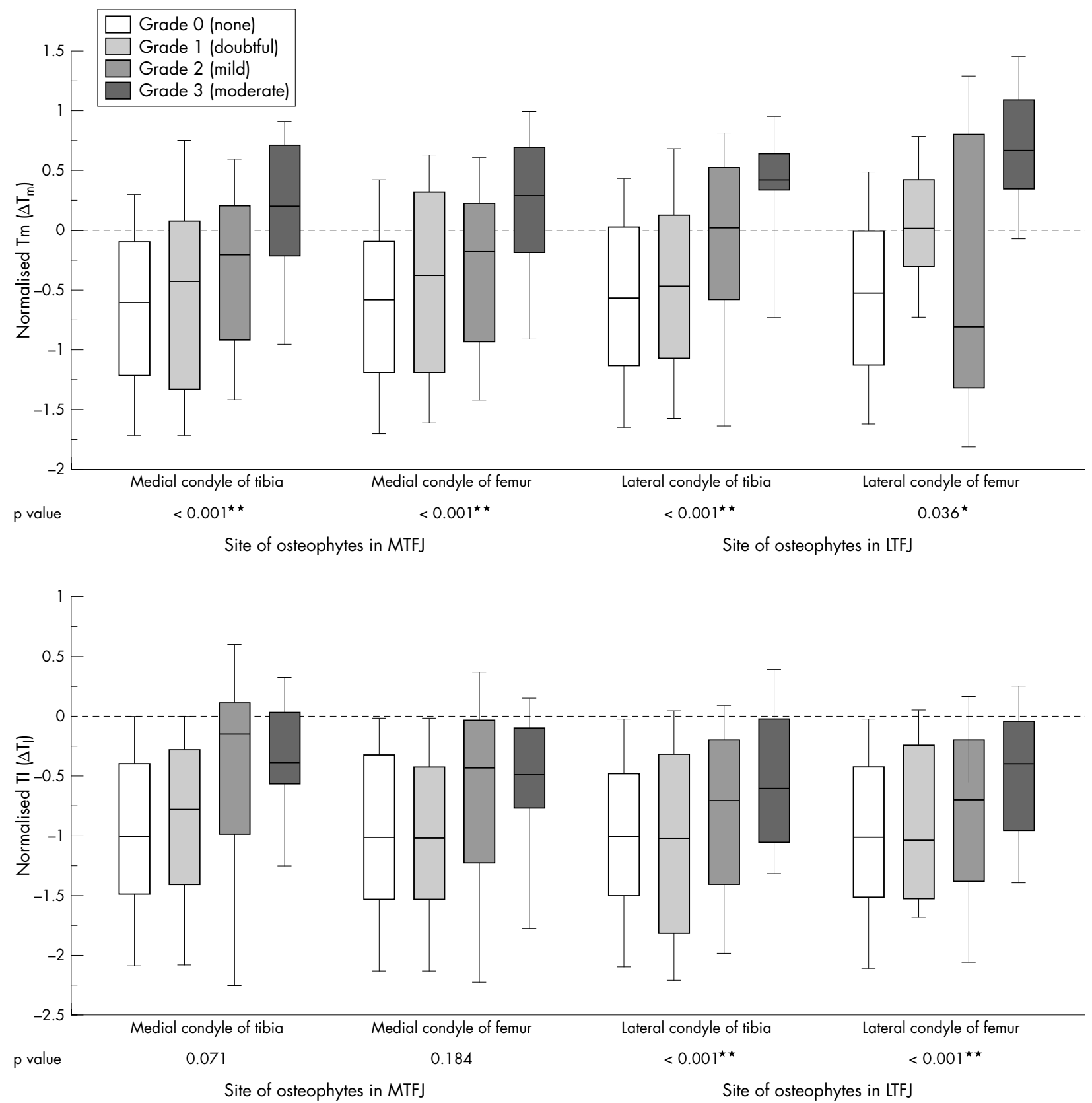

Figure 1 Correlation between the site of the osteophytes and the normalised TI ( $\Delta \mathrm{T}_{\mathrm{m},} \Delta \mathrm{T}_{\|}$. Upper figure: $\Delta \mathrm{T}_{\mathrm{m}}$ and osteophytes in MTFJ and LTFJ; lower figure: $\Delta \mathrm{T}_{1}$ and osteophytes in MTFJ and LTFJ. Larger osteophytes at each site of the MTFJ have a higher skin surface temperature.

data indicate that residents with larger osteophytes in the MTFJ have higher skin surface temperature. We could not find any correlation between HDI and the radiographic findings.

The correlation between skin temperature and clinical symptoms showed that the residents with present or past pain have significantly higher $\Delta \mathrm{T}_{\mathrm{m}}$ or $\Delta \mathrm{T}_{1}(\mathrm{p}<0.01)$. We also found that many clinical findings correlated with the increase of skin temperature indicated by normalised TI $\left(\Delta \mathrm{T}_{\mathrm{m}}\right.$ and $\left.\Delta \mathrm{T}_{1}\right)$, as shown in table 1 . HDI on the knee only correlated with joint swelling and tenderness $(\mathrm{p}<0.01)$.

\section{DISCUSSION}

In this study we used HDI and normalised TI to indicate the skin surface temperature. The normalised TI correlated more significantly with the clinical and radiographic parameters than the HDI. Therefore, it was suggested that the normalised $\mathrm{TI}$ is more useful for evaluation of the disease activity than the
HDI. Further study is needed to confirm the accuracy and sensitivity of normalised TI for the screening of OA.

In the clinical situation raised skin temperature is sometimes seen as local heat in patients with OA in the knee joints. However, as far as we know no published report has assessed the relation between skin temperature and clinical or radiographic findings in OA knees. In this study, thermography provided objective data of skin temperature that was compared with other physical parameters, showing a correlation between skin temperature and clinical, and radiological evidence of OA in the knee joints. Synovial inflammation and subchondral change have been reported to affect the OA cascade. .11 $^{-1}$ Dieppe et al used scintigraphy to show that subchondral bone metabolism is related to the progression and symptoms of OA in the knees. ${ }^{12}$ It is suggested that the skin temperature evaluated by thermography may be due to the increased synovitis or subchondral bone activity, or both, in the OA knee joint. 


\author{
Authors' affiliations \\ H Warashina, Y Hasegawa, H Tsuchiya, S Kitamura, K-I Yamauchi, \\ Y Torii, M Kawasaki, S Sakano, Department of Orthopaedic Surgery, \\ Nagoya University School of Medicine, Nagoya, Aichi, Japan \\ Correspondence to: Dr H Warashina, Department of Orthopaedic \\ Surgery, Nagoya University School of Medicine, 65 Tsurumai-cho, \\ Showa-ku, Nagoya, 466-8550, Japan; warashin@kc4.so-net.ne.jp \\ Accepted 29 January 2002

\section{REFERENCES} \\ 1 Ring EF, Collins AJ, Bacon PA, Cosh JA. Quantitation of thermography \\ in arthritis using multi-isothermal analysis. II. Effect of nonsteroidal \\ anti-inflammatory therapy on the thermographic index. Ann Rheum Dis \\ 1974:33:353-6. \\ 2 Paterson J, Watson WS, Teasdale E, Evans AL, Newman P, James WB \\ et al. Assessment of rheumatoid inflammation in the knee joint. A \\ reappraisal. Ann Rheum Dis 1978;37:48-52. \\ 3 Ito Y, Suzuki S, Yagyu K, Sasaki R, Suzuki K, Aoki K. Relationship \\ between serum carotenoid levels and cancer death rates in the residents, \\ living in a rural area of Hokkaido, Japan. J Epidemiol 1997;7:1-8.
}

4 Tenger Y, Lysholm J. Rating systems in the evaluation of knee ligament injuries. Clin Orthop 1985;198:43-9.

5 Kellgren JH, Lawrence JS. Radiological assessment of osteoarthrosis. Ann Rheum. Dis 1957:16:494-501.

6 Collins AJ, Ring EF, Cosh JA, Bacon PA. Quantitation of thermography in arthritis using multi-isothermal analysis. I. The thermographic index Ann Rheum Dis 1974;33:113-15.

7 Salisbury RS, Parr G, De Silva M, Hazleman BL, Page-Thomas DP. Heat distribution over normal and abnormal joints: thermal pattern and quantification. Ann Rheum Dis 1983;42:494-9.

8 Doherty M. Synovial inflammation and osteoarthritis progression: effects of nonsteroidal anti-inflammatory drugs. OA and Cartilage 1999:7.319-20.

9 Lajeunesse D, Hilal G, Pelletier JP, Pelletier JM. Subchondral bone morphological and biochemical alterations in osteoarthritis. Osteoarthritis Cartilage 1999;7.321-2.

10 Moskowitz RW. Bone remodeling in osteoarthritis: subchondral and osteophytic responses. Osteoarthritis Cartilage 1999;7.323-4.

11 Dieppe P. Subchondral bone should be the main target for the treatment of pain and disease progression in osteoarthritis. Osteoarthritis Cartilage $1999 ; 7.325-6$.

12 Dieppe P, Cushnaghan J, Young P, Kirwan J. Prediction of the progression of joint space narrowing in osteoarthritis of the knee by bone scintigraphy. Ann Rheum Dis 1993;52:557-63.

\section{CD5+ B cells and uveitis}

\section{J Jiménez-Alonso, M Omar, M A López-Nevot, F Pérez-Álvarez, M Toribio, C Hidalgo, J M Sabio}

$\mathrm{H}$ igh levels of circulating Bla lymphocytes expressing CD5 have been reported in some patients with non-organspecific autoimmune diseases, such as systemic lupus erythematosus, primary Sjögren's syndrome, and rheumatoid arthritis, although CD5+ B cells do not seem to be only agents of autoantibody production. ${ }^{1}$ Thus, B cells display a variety of characteristics other than antibody production-for example, in lymphoid architecture development, regulation of T cell subsets and antigen presenting cell function through cytokine production, and in activation of T cells. ${ }^{2}{ }^{3}$ In addition, CD $5+\mathrm{B}$ cells have a role in several organ-specific autoimmune diseases, such as chronic urticaria, ${ }^{4}$ insulin dependent diabetes mellitus, ${ }^{5}$ myasthenia gravis, ${ }^{6}$ and immune thrombocytopenic purpura, where the increased proportion of $\mathrm{CD} 5+\mathrm{B}$ cells in spleen and peripheral blood, and their ability to produce antiplatelet antibodies, indicates that they are directly involved in the pathogenesis. ${ }^{7}$ Furthermore, Liversidge et al isolated CD5+ B lymphocytes and TCR $\gamma-\delta$ T lymphocytes from the vitreous humor of a patient with acute sympathetic ophthalmitis ${ }^{8}$; Sampalo et al found a correlation between CD5 + B cells and HIV disease progression'; and Printz et al discovered that a subset of patients with schizophrenia had raised levels of CD5+ B cells, which provides evidence suggestive of autoimmune manifestations in schizophrenia. ${ }^{10}$

Uveitis is a general term denoting any type of intraocular inflammatory disease, which may be of unknown origin or associated with many general diseases. ${ }^{11-14}$ Although immunological disturbances play a part in the pathogenesis of uveitis, it is still difficult to understand the mechanism by which tissue damage is mediated; further research is needed. ${ }^{15}$ Since 1989 the uveitis unit of our hospital has comprised an interdisciplinary team of internists and ophthalmologists studying the cause of uveitis in patients with uveitis of unknown origin. By 2000 we had prospectively studied 315 patients with uveitis, none of whom had been previously diagnosed with systemic diseases which might have been caused by uveitis. We aimed at evaluating the average level of CD5 + B cells in peripheral blood from 27 patients with idiopathic uveitis (20 with anterior uveitis, seven, with posterior uveitis) and 21 healthy subjects matched for age and sex who served as control group. Patients were consecutively enrolled between May 1999 and November 2000, and the control group was recruited from the hospital staff. Double labelling with $\mathrm{CD} 5$ and $\mathrm{CD} 19$ monoclonal antibodies (BD Oncomark CD5 FITC/CD10 PE/CD19 perCP-Cy5.5; Becton Dickinson, California, USA) was used for lymphocyte staining. The flow cytometry analysis was carried out with a FACScan cytometer. Statistical analysis was performed with a $t$ test for independent continuous variables and Fisher's exact test for categorical variables.

The mean (SD) level of CD5 + B cells in peripheral blood was found to be significantly higher in the 27 patients with uveitis (91 (76) cells $\times 10^{6} /$; percentage $\left.28(20)\right)$ than in the control group (58 (34) cells $\times 10^{6} / 1$; percentage 18 (5)); $\mathrm{p}<0.05)$. Moreover, we also found increased levels of CD5 + B cells in various subgroups of uveitis-namely, anterior uveitis (94 (79) cells $\times 10^{6} / 1$; percentage 29 (19)) and clinically severe cases of uveitis $\left(108(93)\right.$ cells $\times 10^{6} /$; percentage $\left.34(21)\right)$, which were significantly different from those in control subjects $(\mathrm{p}<0.05)$. However, no significant differences were found between anterior and posterior uveitis subgroups, or between unilateral and bilateral disease, or between single and repeated episodes of inflammation.

Thus, CD5 + B cells may lead to uveitis by acting as antigen presenting cells, stimulating CD4 $+\mathrm{T}$ cells with an unknown antigen. Patients with non-organ-specific and organ-specific autoimmune diseases, such as uveitis, may have increased levels for CD5 + B cells, which indicates an immunoregulatory role of CD5 + B cells in autoimmunity, and suggests that effective ways of testing and controlling the immune response in patients with uveitis might be devised.

\section{Authors' affiliations}

J Jiménez-Alonso, M Omar, F Pérez-Álvarez, C Hidalgo, J M Sabio, Systemic Autoimmune Diseases Unit, Services of Internal Medicine,

"Virgen de las Nieves" University Hospital, Granada, Spain 
M A López-Nevot, Clinical Immunology, "Virgen de las Nieves" University Hospital

M Toribio, Ophthalmology, "Virgen de las Nieves" University Hospital

Correspondence to: Dr J Jiménez-Alonso, 9th floor, Hospital Universitario "Virgen de las Nieves", Avda Fuerzas Armadas No 2, 18012 Granada, Spain; jualso@hvn.sas.cica.es

Accepted 25 February 2002

\section{REFERENCES}

1 Youinou P, Lydyard PM. CD5+ B cells in nonorgan-specific autoimmune diseases: a fresh look. Lupus $2001 ; 10: 523-5$.

2 Porakishvili N, Mageed R, Jamin C, Pers JO, Kulikova N, Renaudineau $Y$, et al. Recent progress in the understanding of B-cell functions in autoimmunity. Scand J Immunol 2001;54:30-8

3 Poussin MA, Goluszko E, Hughes TK, Duchicella SI, Christadoss P. Suppression of experimental autoimmune myasthenia gravis in IL-10 gene-disrupted mice is associated with reduced $B$ cells and serum cytotoxicity on mouse cell line expressing AChR. J Neuroimmunol 2000; $111: 152-60$

4 Toubi E, Adir-Shani A, Kessel A, Shmuel Z, Sabo E, Hacham H. Immune aberrations in $\mathrm{B}$ and $\mathrm{T}$ lymphocytes derived from chronic urticaria patients. J Clin Immunol 2000;20:371-8.

5 Gyarmati J, Szekeres-Bartho J, Fischer B, Soltesz G. Fetal type lymphocytes in insulin dependent diabetes mellitus. Autoimmunity 1999;30:63-9.

6 Lee KW, Lee SH, Kim HJ, Kim JM, Choi YM, Motomura M. Experimenta autoimmune myasthenia gravis and CD5+ B-lymphocyte expression. J Korean Med Sci 1999; 14:75-9.
7 Mizutani H, Furubayashi T, Kashiwagi $\mathrm{H}$, Hondas S, Take H, Kurata $\mathrm{Y}$, et al. B cells expressing CD5 antigen are markedly increased in peripheral blood and spleen lymphocytes from patients with immune thrombocytopenic purpura. Br J Haematol 1991;78:474-9.

8 Liversidge J, Dick A, Cheng YF, Scott GB, Forrester JV. Retinal antigen specific lymphocytes, TCR-gamma delta T cells and CD5+ B cells cultured from the vitreous in acute sympathetic ophthalmitis. Autoimmunity 1993; 15:257-66.

9 Sampalo A, López-Gómez M, Jiménez-Alonso J, Ortíz F, Samaniego F, Garrido F. CD5 + B lymphocytes in HIV infection: relationship to immunological progression of disease. Clin Immunol Immunopathol 1993;66:260-8

10 Printz DJ, Strauss DH, Goetz R, Sadiq S, Malaspina D, Krolewski J, ef al. Elevation of CD5+ B lymphocytes in schizophrenia. Biol Psychiatry 1999:46:110-18.

11 Herranz Marín MT, Jiménez-Alonso J, Delgado Rodríguez M, Omar M Rivera-Cívico F, Mar-Armada M, et al. Marcadores clinicobiológicos de uveitis secundaria: resultados de un análisis discriminante. Med Clin (Barc) 1997:109:786-91.

12 Herranz MT, Jiménez-Alonso J, Martín-Armada M, Omar M, Ribera F. Increased prevalence of NIDDM in anterior uveitis. Diabetes Care 1997;20: 1797-8.

13 Rivera-Cívico F, Jiménez-Alonso J, Martín-Armada $M$, Herranz MT, Castro J, Pérez-Álvarez F, et al. HLA-B27+ anterior uveitis with or withou associated spondyloarthritis: clinical and immunological features. Ann Rheum Dis 1999.58:721-2.

14 Jiménez-Alonso J, Martín-Armada M, Toribio M, Herranz-Marín MT, Rivera-Cívico F, Pérez-Álvarez F. Incidence of systemic lupus erythematosus among 255 patients with uveitis of unknown origin. Ann Rheum Dis 2002;61:471.

15 Poulaki V, Mitsiades N, Mastorakos G, Caspi RR, Chrousos GP, Bouzas $E$. Fas/Fas ligand-associated apoptosis in experimental autoimmune uveoretinitis in rodents: role of proinflammatory corticotropin-releasing hormone. Exp Eye Res $2001 ; 72: 623-9$

\section{Absence of human parvovirus B19 DNA in myoepithelial sialadenitis of primary Siögren's syndrome}

\section{De Re, S De Vita, V Battistella, A Marzotto, M Libra, G Ferraccioli, M Boiocchi}

S ögren's syndrome (SS) is an autoimmune disease that mainly affects exocrine glands and presents as persistent dryness of the mouth and eyes owing to functional impairment of the salivary and lachrymal glands. The histological hallmark is local infiltration of lymphocytes, which play a major role in tissue damage. Although B cells represent a minority of the lymphoid infiltrates in SS tissue, they may undergo polyclonal activation and oligoclonal/monoclonal expansion, which may, in turn, predispose them to a still unidentified B cell neoplastic transformation. The process of $\mathrm{B}$ cell activation and expansion is presumably a consequence of a chronic, although at present unidentified, antigenic stimulus that activates specific subsets of B lymphocytes. ${ }^{12}$ This process resembles a germinal centre reaction, in which B cells that express the antigen receptor with the highest affinity for the stimulatory antigen are selected, giving rise to the oligoclonal/monoclonal population seen in the advanced phases of the disease. ${ }^{12}$

We recently analysed seven monoclonal lymphoproliferations from six patients with primary $\mathrm{SS}^{1}$ according to the European Criteria of 1993'; (one patient with SS showed a different monoclonal B cell population in two subsequent parotid specimens). DNA was extracted from frozen parotid biopsy specimens, and a $\mathrm{B}$ cell monoclonal expansion was verified by the VDJ protocol of amplification. ${ }^{1}$ The immunoglobulin antigen receptor (IgR) variable region genes and third complementarity determining region segments (CDR3), which mainly contribute to the antigenic specificity of the IgR, were sequenced. ${ }^{1}$
Comparison of the deduced amino acid sequences of the CDR3 region with antibodies of known specificity reported in a database, showed in six cases a high similarity between VH CDR3 and rheumatoid factor (RF) antibodies, presumably autoantibodies produced against an infectious agent(s), and in one case an antibody putatively reactive with parvovirus B19 (table 1). ${ }^{1}$ This suggests that RF producing cells have a role in SS pathogenetic events, as recently confirmed by Martin et al. ${ }^{4}$

Because human parvovirus B19 is a common DNA virus, present in $30-60 \%$ of the population positive to $\mathrm{B} 19$ antibodies, ${ }^{5}$ which infects not only erythrocytes and erythroblasts but also megakaryocytes, endothelial and epithelial cells $^{6}$ and is possibly involved in several autoimmune diseases, ${ }^{7-9}$ we searched for B 19 genomes in tissues affected by the SS associated lymphoproliferative processes. This was in agreement with the proposed models for the pathogenesis of MALT lymphoma. ${ }^{10}$

A polymerase chain reaction (PCR) amplification using the Ampliquality B19 kit (Ab ANALITICA srl, Padova, Italy) was performed, in accordance with the manufacturer's instructions, to search for the presence of B19 DNA directly in the parotid specimens affected by SS. The PCR products were analysed on $2 \%$ agarose gel stained with ethidium bromide. Positive cases must show a fragment of $218 \mathrm{bp}$, which derives from amplification of the 1390 to 1608 region of the viral genome.

The region encoding for the $\beta$-globin gene was also amplified by PCR to confirm the quality of DNA (data not shown).

Despite the high sensitivity of the PCR approach, B19 DNA was not detected in patient 5, who showed a high homology of 
Table 1 Deduced amino acid sequences of VH-CDR3 and VK-CDR3 and high similarity with protein sequence with known antigenic specificity

\begin{tabular}{|c|c|c|c|c|}
\hline Cases & $\begin{array}{l}\text { Most similar VH or VK } \\
\text { germline segments }\end{array}$ & $\begin{array}{l}\text { VH-CDR3 or VK-CDR3 deduced } \\
\text { amino acid sequences }\end{array}$ & $\begin{array}{l}\text { Protein sequence with known specificity } \\
\text { producing a high significant similarity } t\end{array}$ & E Value* \\
\hline \multicolumn{5}{|l|}{$\mathrm{VH}$} \\
\hline 1 & V4-59; D2-15; J2 & DRYCSGGSCFDWYFD & (U85234) rheumatoid factor & $6 e-08$ \\
\hline 2 & V3-7; D3-22; J3 & GDYYDSSDYYIDAFDI & (U03400) rheumatoid factor & 0.48 \\
\hline 3 & V4-59; D2-15; J2 & DRYCSGGSCFDWYFD & (U85234) rheumatoid factor & $8 \mathrm{e}-08$ \\
\hline 4 & V3-11; D3-22; J3 & GDYYDSSDSFHDVLI & (U85242) rheumatoid factor & 0.002 \\
\hline 5 & V3-7; D1-20; J3 & DLTRRPESDAFDI & (AF092498) antibody against parvovirus B19 & 0.025 \\
\hline 6 & V1-8; D7-27; J6 & APSWATNYFYYGMDV & (AAB58433) rheumatoid factor & $6 e-04$ \\
\hline 7 & V1-69; D5-18; J4 & EGHKDTTMVTPFDY & (L19288) rheumatoid factor & $3 e-06$ \\
\hline \multicolumn{5}{|c|}{ f } \\
\hline 1 & V3-20; J1 & QQYGSSPRTF & (225028) rheumatoid factor & 0.074 \\
\hline 2 & V3-20; J3 & QQYGTSPFT & (L40727) rheumatoid factor & 0.073 \\
\hline 3 & V3-20; J1 & QQYGSSPRT & (225028) rheumatoid factor & 0.073 \\
\hline 4 & V3-15; J1 & QHYNNWPPWT & (S67061) rheumatoid factor & 0.025 \\
\hline 5 & V3-15; J1 & QQYNNWPPWT & (L48242) rheumatoid factor & \\
\hline 6 & V3-20; J1 & QQYGSSPPYS & (227950) rheumatoid factor & 3.3 \\
\hline 7 & V3-20; J4 & QQYGNSPLT & (L19293) rheumatoid factor & 0.16 \\
\hline
\end{tabular}

* Smallest sum probability according to BLAST similarity search programme. The E value is inversely correlated with statistical significance. The search in the database was performed adding 3 AA in position $5^{\prime}$ and 7 AA in position $3^{\prime}$ to the CDR3 sequence for the VH gene and 1 AA in position $5^{\prime}$ and 4 AA in position 3' for the VK gene; the GenBank accession number of the protein sequence is reported in brackets.

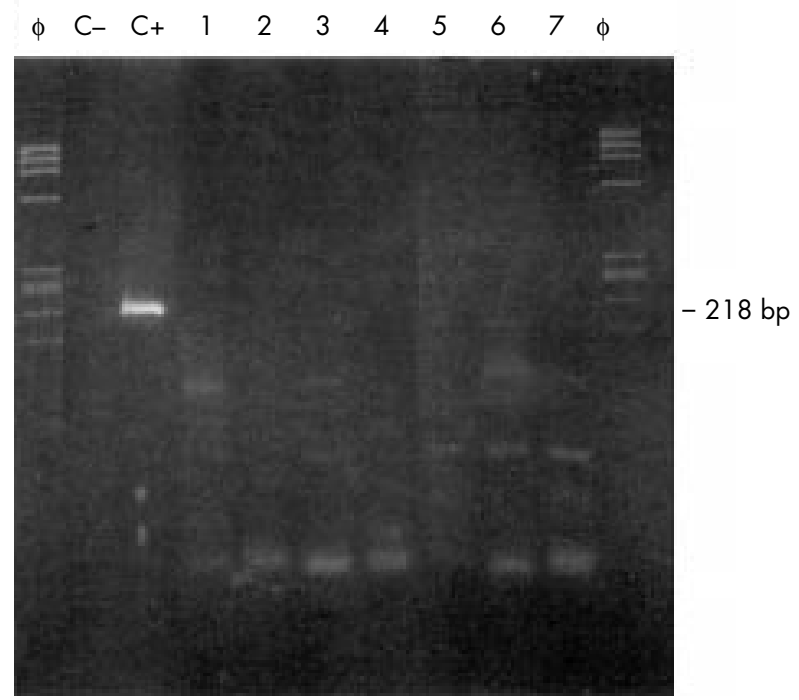

Figure 1 The product of B 19 amplification was run through a $2 \%$ agarose gel. The positive control $(\mathrm{C}+)$, included in the kit, showed a $218 \mathrm{bp}$ band corresponding to the 1390 to $1608 \mathrm{bp}$ region of $\mathrm{B} 19$. Patient numbers are reported at the top of the lanes. Lane Ccorresponds to a negative control deprived of DNA.

VH CDR3 to anti-B19 antibody; neither was it detected in the other patients (fig 1). These results, according to the proposed model for MALT lymphomagenesis, therefore exclude B19 infection as a local stimulus for parotid MALT lymphoproliferation in SS.

\section{ACKNOWLEDGEMENTS}

The authors thank Dr P Tonel for help with the letter. Supported in part by the Italian Association for Cancer Research.

\section{Authors' affiliations}

V De Re, V Battistella, A Marzotto, M Boiocchi, Division of Experimental Oncology 1, Centro di Riferimento Óncologico, Avian, Italy S De Vita, G Ferraccioli, Division of Rheumatology, DPMSC, University of Udine, Italy

M Libra, Department of Biomedical Science, Clinical Pathology and Molecular Oncology Section, University of Catania, Italy

Correspondence to: Dr M Boiocchi, Experimental Oncology 1, Centro di Riferimento Oncologico, via Pedemontana Occidentale 12, 33081 Aviano (PN), Italy; mboiocchi@cro.it

Accepted 25 February 2002

\section{REFERENCES}

1 De Re V, De Vita S, Gasparotto D, Marzotto A, Carbone A, Ferraccioli GF, et al. Salivary gland B-cell lymphoproliferative disorders in Sjögren's syndrome present a restricted use of antigen-receptor gene segments similar to those used by hepatitis $C$ virus-associated non Hodgkin's ymphomas. Eur J Immunol (in press).

2 Miklos JA, Swerdlow SH, Bahler DW. Salivary gland mucosa-associated lymphoid tissue lymphoma immunoglobulin $\mathrm{V}(\mathrm{H})$ genes show frequent use of V1-69 with distinctive CDR3 features. Blood 2000;95:3878-84.

3 Vitali C, Bombardieri S, Moutsopoulos HM, Balestrieri G, Bencivelli W, Bernstein RM, et al. Preliminary criteria for the classification of Siögren's syndrome. Results of a prospective concerted action supported by the European Community. Arthritis Rheum 1993:36:340-7.

4 Martin T, Weber JC, Levallois H, Labouret N, Soley A, Koenig S, et al. Salivary gland lymphomas in patients with Siögren's syndrome may frequently develop from rheumatoid factor B cells. Arthritis Rheum 2000;43:908-16.

5 Adler SP, Manganello AM, Koch WC, Hempfling SH, Best AM. Risk of human parvovirus B19 infections among school and hospital employees during endemic periods. J Infect Dis 1993;168:361-8.

6 Rios $M$, Bianco $C$. The role of blood group antigens in infectious diseases. Semin Hematol 2000;37:177-85

7 Lunardi C, Tiso M, Borgato L, Nanni L, Millo R, De Sandre G, et al. Chronic parvovirus $B 19$ infection induces the production of anti-virus antibodies with autoantigen binding properties. Eur J Immunol 1998;28:936-48.

8 Ramos-Casals M, Cervera R, Garcia-Carrasco M, Vidal J, Trejo O, Jimenez $S$, et al. Cytopenia and past human parvovirus $B 19$ infection in patients with primary Sjögren's syndrome. Semin Arthritis Rheum patients with primary

9 Takahashi Y, Murai C, Shibata S, Munakata Y, Ishii T, Ishii K, et al Human parvovirus $B 19$ as a causative agent for rheumatoid arthritis. Proc Natl Acad Sci USA 1998;95:8227-32.

10 Cammarota G, Papa A, Tursi A, Cuoco L, Fedeli G, Gasbarrini G. Pathogenesis of MALT lymphoma: an antigen-dependent process. Gastroenterology 1997;113:1810. 


\title{
Spectrum of psoriatic spondyloarthropathy in a cohort of 100 Spanish patients
}

\author{
R Queiro, C Sarasqueta, J C Torre, T Tinturé, I López-Lagunas
}

Ann Rheum Dis 2002;61:857-858

p $\mathrm{n}$ their initial work, Moll and Wright recognised five patterns of psoriatic arthritis (PsA)-namely, distal joint disease, oligoarthritis, polyarthritis, arthritis mutilans, and spondylitis. ${ }^{1}$ Although psoriatic spondyloarthropathy was recognised as a specific pattern of PsA, it has become clear that the presence of isolated spondyloarthropathy ( $\mathrm{SpA}$ ) in PsA is unusual, and in most cases, it occurs with peripheral arthritis. ${ }^{23}$ We undertook the present work to analyse the clinical features of our patients with psoriatic SpA and to compare the different subgroups included within the psoriatic SpA spectrum.

One hundred patients with psoriatic SpA, defined in accordance with the European Spondyloarthropathy Study Group (ESSG) criteria, ${ }^{4}$ were consecutively recruited and their clinical records were analysed in this retrospective cross sectional study. All patients were evaluated according to a standard protocol, and their functional ability was assessed using the Health Assessment Questionnaire-Specific for SpA (HAQ-S). ${ }^{5}$ We included patients with isolated axial involvement, as well as those with axial plus peripheral disease. The study group was divided according to the articular patterns seen during the past five years of follow up. The presence of mutilans forms and distal interphalangeal (DIP) disease was also recorded.
We performed HLA-B27 typing by serological methods and HLA-Cw typing by molecular biology techniques (SSOP-PCR) in our 100 patients and in 177 blood donors of the same racial origin.

Sacroiliac radiographic changes were graded as follows: 0, normal; 1, possible; 2 , minimal; 3, moderate; and 4, ankylosis. All symptomatic joints were radiographed. At least two senior rheumatologists read all $x$ ray films, and there was a complete agreement, except for three cases, where consensus was achieved.

Categorical data were analysed by Pearson's $\chi^{2}$ analysis and Fisher's exact test, whereas continuous data were compared by analysis of variance. Relative risk (RR) was calculated by Woolf's method. ${ }^{6}$

According to the clinical patterns seen during the past five years of follow up, 23 patients developed isolated axial disease only ( M:F ratio 3.6:1), 36 showed a mixed pattern of axial disease and polyarthritis (M:F ratio 1:1), and 41 had oligoaxial disease (M:F ratio 1.7:1).

Thirty four patients carried the HLA-B27 antigen compared with a normal distribution of this allele of $7 \%$ in the control group (RR 7, p <0.0004), whereas HLA-CW*0602 was seen in 58 of the 100 patients compared with a frequency in the control group of $18 \%$ (RR 6.2, $p<0.0001$ ). This last allele was equally distributed among the three articular categories.

\begin{tabular}{|c|c|c|c|c|}
\hline Variables & $\begin{array}{l}\text { Pure axial } \\
\text { pattern }(n=23)\end{array}$ & $\begin{array}{l}\text { Polyaxial } \\
\text { pattern }(n=36)\end{array}$ & $\begin{array}{l}\text { Oligoaxial } \\
\text { pattern }(n=41)\end{array}$ & $\mathrm{p}$ Values \\
\hline Age (years) & $43(11)$ & $54(12)$ & $46(15)$ & 0.039 \\
\hline Psoriasis duration (years) & $16(9)$ & $19(8)$ & $17(11)$ & NS \\
\hline Arthritis duration (years) & $10(6)$ & $13(7)$ & $10(5)$ & NS \\
\hline Psoriasis onset age (years) & $27(10)$ & 35 (13) & 29 (14) & NS \\
\hline Arthritis onset age (years) & $33(8)$ & $40(12)$ & $37(15)$ & NS \\
\hline Psoriasis-arthritis latency (years) & $8(4)$ & $8(7)$ & $14(10)$ & 0.07 \\
\hline Family history (\%) & 17 & 19 & 22 & NS \\
\hline $\operatorname{IBP}(\%)$ & 83 & 36 & 37 & 0.009 \\
\hline Neck pain (\%) & 22 & 25 & 27 & NS \\
\hline Radiological neck involvement (\%) & 35 & 56 & 39 & NS \\
\hline Marginal syndesmophytes (\%) & 26 & 19 & 19 & NS \\
\hline Para-marginal syndesmophytes (\%) & 13 & 28 & 24 & NS \\
\hline Bilateral SI (\%) & 56 & 31 & 37 & NS \\
\hline Unilateral SI (\%) & 44 & 44 & 48 & NS \\
\hline Onychopathy (\%) & 30 & 75 & 51 & 0.015 \\
\hline ESR $(\mathrm{mm} / 1 \mathrm{st} \mathrm{h})$ & $27(20)$ & $47(26)$ & $20(21)$ & 0.0001 \\
\hline $\mathrm{CRP}(\mathrm{mg} / \mathrm{l})$ & $160(250)$ & $190(160)$ & $100(130)$ & NS \\
\hline C3 (g/l) & $1.3(0.3)$ & $1.2(0.3)$ & $1.2(0.3)$ & 0.037 \\
\hline $\mathrm{C} 4 \mathrm{lg} / \mathrm{l})$ & $0.3(0.1)$ & $0.2(0.1)$ & $0.3(0.1)$ & 0.045 \\
\hline $\lg G(g / l)$ & $13.70(2.60)$ & $16.05(5.00)$ & $12.17(2.80)$ & 0.029 \\
\hline $\lg M(g / I)$ & $1.93(1.02)$ & $1.71(0.73)$ & $1.55(0.89)$ & NS \\
\hline $\lg A(g / l)$ & $3.12(1.42)$ & 2.85 (1.29) & $2.86(1.86)$ & NS \\
\hline Erosive disease (\%) & $4^{*}$ & 75 & 37 & 0.0001 \\
\hline DIP disease (\%) & 17 & 64 & 51 & 0.015 \\
\hline HLA-B27 (\%) & 57 & 19 & 29 & 0.016 \\
\hline Uveitis (\%) & 30 & 11 & 10 & 0.022 \\
\hline Schober's test $(\mathrm{cm})$ & $2.5(0.3)$ & $2.7(0.5)$ & $2.8(0.4)$ & NS \\
\hline HAQ-S (mean) & $1.4(0.4)$ & $1.8(0.4)$ & $1.5(0.3)$ & 0.03 \\
\hline
\end{tabular}


Table 1 compares the articular categories found in this study.

A satisfactory definition is still lacking for PsA, in particular for psoriatic SpA, and therefore we reported only those cases fulfilling the criteria given by the ESSG ${ }^{4}$ in order to standardise our observations and to enable comparisons with other past or future reports.

After a minimum of five years of observation, we have found that three clear patterns of psoriatic SpA are easy to document-namely, isolated axial disease, polyaxial disease, and oligoaxial pattern. Moreover, DIP disease and mutilans forms did not remain as independent patterns over time.

Patients with isolated axial disease were more often men, and had more clinical (inflammatory back pain), radiological (bilateral sacroiliitis and marginal syndesmophytes), immunogenetic (HLA-B27), and extra-articular (uveitis) features which strongly correlate this group with idiopathic ankylosing spondylitis. We found that the spondylitic process was similar between groups, though patients with polyaxial disease had more neck radiological damage than the other patients, probably because this group had more peripheral erosions and a longer duration of arthritis (table 1). Involvement of the neck was associated with arthritis duration $(\mathrm{p}=0.043)$ and peripheral erosions $(p=0.037)$, confirming previous reports. ${ }^{7}$

Unquestionably, more than $50 \%$ of patients with PsA have DIP joint disease, but the presence of isolated DIP disease is still controversial, as is its role as a prognostic marker. ${ }^{8}$ Our observations suggest that DIP disease is a typical feature of PsA rather than an additional articular category, and that it is mostly associated with peripheral forms of the disease; indeed, the highest percentages of onychopathy and DIP disease were seen among patients with the polyaxial pattern, whereas the lowest percentages were found in the group with isolated axial disease (table 1). This latter observation is at odds with the supposed association between DIP disease and sacroiliitis or the reported association between HLA-B27 and DIP disease. ${ }^{8}$ We have obtained data which point not only to a different genetic basis in psoriatic SpA models but also to different pathogenic mechanisms. As a whole, in our study HLAB27 was a stronger risk factor for isolated and oligoaxial variants of psoriatic SpA than for the polyaxial one. In this last group we found higher rates of complement consumption, more peripheral erosions, poorer functional performance, and higher immunoglobulin ( $\operatorname{IgG}$ ) values, supporting the view that immunocomplexes may be an important mechanism of tissue injury in psoriatic polyarthritis. ${ }^{9}$ On the other hand, the ileocolonoscopic studies of Schatteman et al found gut lesions resembling those of inflammatory bowel disease in patients with psoriatic oligoarthritis and spondylitis but not in patients with psoriatic polyarthritis. ${ }^{10}$

In summary, some HLA, clinical and pathogenic data support the subdivision of psoriatic SpA as proposed in the present report.

\section{Authors' affiliations}

R Queiro, T Tinturé, I López-Lagunas, Rheumatology Unit and Internal Medicine Service. Hospital San Agustín, Camino de Heros 4, 33400

Avilés-Asturias, Spain

C Sarasqueta, Clinical Epidemiology Unit, Hospital Nuestra Sra De

Aránzazu, San Sebastian-Guipúzcoa, Spain

J C Torre, Rheumatology Unit, Hospital Monte Naranco,

Oviedo-Asturias, Spain

Correspondence to: $\operatorname{Dr} R$ Queiro, C/Marcelino Fernández 7, 3B, 33010 Oviedo-Asturias, Spain; ruquei@mixmail.com

Accepted 12 February 2002

\section{REFERENCES}

1 Moll JMH, Wright V. Psoriatic arthritis. Semin Arthritis Rheum 1973;3:55-78

2 Torre Alonso JC, Rodriguez Perez A, Arribas Castrillo JM, Ballina Garcia J, Riestra Noriega JL, Lopez Larrea C. Psoriatic arthritis (PA): a clinical, immunological and radiological study of 180 patients. $\mathrm{Br} J$ Rheumatol 1991:30:245-50.

3 Marsal S, Armadans Gil L, Martinez M, Gallardo D, Ribera A, Lience E. Clinical, radiographic and HLA associations as markers for the different patterns of psoriatic arthritis. Rheumatology (Oxford) 1999;38:332-7.

4 Dougados M, van der Linden SM, Jhulin R. The European Spondyloarthropathy Study Group preliminary criteria for the classification of spondyloarthropathy. Arthritis Rheum 1991;34:121827.

5 Daltroy LH, Larson MG, Roberts WN, Liang MH. A modification of the Health Assessment Questionnaire for the spondyloarthopathies. J Rheumatol 1990;17:946-50.

6 Woolf B. On estimating the relation between blood groups and disease. Ann Hum Genet 1955;19:251-3

7 Salvarani C, Macchioni P, Cremonesi T, Mantovani W, Battistel B, Rossi $\mathrm{F}$, et al. The cervical spine in patients with psoriatic arthritis: a clinical, radiological and immunogenetic study. Ann Rheum Dis 1992:51:73-7.

8 Gladman DD. Psoriatic arthritis. Rheum Dis Clin North Am Gladman DD. Pso
1998;24:829-43.

9 Rivas D, Riestra JL, Torre Alonso JC, Rodriguez A, Gutierrez Martin C. Decrease in detectable complement receptor type I from erythrocytes from patients with psoriatic polyarthritis. Br J Rheumatol 1994;33:626-30.

10 Schatteman L, Mielants H, Veys EM, Cuvelier C, De Vos M, Gyselbrecht L, et al. Gut inflammation in psoriatic arthritis: a prospective ileocolonoscopic study. J Rheumatol 1995:22:680-3. 